\title{
Phytoaccumulation of Zinc and its associated impact on the growth performance and tolerance index of six bioenergy crop plants grown in Zn- contaminated soil
}

Hanan El-Sayed Mohamed Osman ( $\square$ hananosman1@gmail.com )

Umm Al-Qura University https://orcid.org/0000-0003-0612-842X

Afnan Sami Quronfulah

Umm Al-Qura University

Mohamed EIMorsy

Umm Al-Qura University

Tarek M. Galal,

Helwan University Faculty of Science

\section{Research Article}

Keywords: Zinc, bioenergy crops, phytoremediation, tolerance index, bioaccumulation

Posted Date: February 28th, 2022

DOI: https://doi.org/10.21203/rs.3.rs-1273917/v1

License: (c) (i) This work is licensed under a Creative Commons Attribution 4.0 International License.

Read Full License 


\title{
Phytoaccumulation of Zinc and its associated impact on the growth performance and
}

\section{tolerance index of six bioenergy crop plants grown in Zn-contaminated soil}

\begin{abstract}
\end{abstract}
Crop plant remediation and reclamation of $\mathrm{Zn}$-contaminated soils may pose a serious threat to food safety and thus human health. As a result, the current study was carried out to assess the capability of six bioenergy crop plants (BCP): Zea mays hybrid 360, Z. mays hybrid 123, Helianthus annus, Brassica juncea, Ricinus communis, and Simmondsia chinensis to remediate and restore $\mathrm{Zn}$-contaminated soils. The investigated plants can tolerate $150 \mathrm{mg} \mathrm{kg}^{-1} \mathrm{Zn}$ content of the soil, where they had tolerance index (TI) $>1$ for all growth criteria, except the root dry weight (DW) of S. chinensis. Z. mays T123 and R. communis were the most susceptible plants, while $B$. juncea and $S$. chinensis were moderately tolerant, and $H$. annus was the most tolerant to high $\mathrm{Zn}$ concentrations. Increasing the soil $\mathrm{Zn}$-content led to a significant $(p<0.05)$ increase in the concentration of $\mathrm{Zn}$ in the different tissues of the six BCP. The study BCP did not translocate $\mathrm{Zn}$ to their grains/seeds, and consequently they can be used safely in $\mathrm{Zn}$ phytoremediation from $\mathrm{Zn}$ contaminated soils. The root and shoot $\mathrm{Zn}$-content was negatively correlated with the TI of the root and shoot length and weight, while the $\mathrm{TF}$ of $\mathrm{Zn}$ from root to shoot was significantly proportional to the TI of the root length and weight. According to phytoremediation efficiency, the six study BCP were arranged as follow: B. juncea $(31.9 \%)>$ Z. mays T123 (31.1\%) > Z. mays T360 $(27.6 \%)>H$. annus $(20.8 \%)>$ S. chinensis $(20.3 \%)>R$. communis $(15.3 \%)$. All tested BCP had high Zn concentrations in their roots and shoots, a high Zn uptake potential, and a high biomass at $150-450 \mathrm{mg} \mathrm{kg}^{-1} \mathrm{Zn}$ treatments, indicating that these plants are good candidates for the implementation of new strategy of cultivating BCP for phytoremediation in $\mathrm{Zn}$-contaminated soils. Keywords: Zinc, bioenergy crops, phytoremediation, tolerance index, bioaccumulation 


\section{Introduction}

Heavy metal pollution is a serious problem in most countries around the world, and it can be caused by both natural and anthropogenic processes (Lajayer et al. 2019). Over the last few decades, urbanization and rapid industrialization have led to a significant increase in soil contamination with heavy metals like zinc (Bolan et al. 2014). Metal pollutants occur in soils in various forms and can pose a threat to soil components leading to soil degradation, a reduction in crop growth by interfering with their enzymatic reactions, photosynthetic activity, and nutrient homeostasis (Wei et al. 2021). These metals can also accumulate in the human body via the food chain, causing a variety of health issues such as nervous system disorders, brain, kidney, and liver damage, cardiomyopathy, cancer, and endocrine, nervous, and immune system impairments (Rai et al. 2019; Hu et al. 2020).

Zinc is an essential micronutrient for terrestrial plant growth and development, and it is the second most abundant and common metal in living organisms (Sidhu 2016). It plays a vital role in various physiological processes, including nucleic acid, lipid, and carbohydrate metabolism; enzyme activation; protein synthesis; and reproductive development (Grassi et al. 2020; Li et al. 2022). Nevertheless, Zn polluted soil is considered a major concern for global crop production (Miretzky et al. 2004). It is commonly found in high concentrations in wastewater from various industries, particularly mining, fertilizer industries, batteries, metal galvanization, pesticides, municipal sewage, and tire wear from automobile traffic (Rauch and Pacyna 2009; Dmuchowski et al. 2014). The main issue with $\mathrm{Zn}$ is its non-biodegradability and dispersion through an ecosystem's various trophic levels, as well as its persistence in nature (Elleuch et. al. 2021). Under such circumstances, high content of $\mathrm{Zn}$ accumulates in plant tissues and can reach to toxic concentration (> $300 \mathrm{mg} \mathrm{kg}^{-1}$ ), which cause growth inhibition and physiological changes by reducing the contents of essential elements like $\mathrm{Mn}, \mathrm{Cu}$, and Fe (Connolly et al. 2003; Sagardoy 
49 et al. 2009). Numerous physiological processes could be affected as a result of a high concentration

50 of $\mathrm{Zn}$ such as altering photosynthetic activity, damaging oxidative membranes, inhibiting the

51 synthesis of photosynthetic pigments, and electron transport (Vassilev et al. 2007; Yahaghi et al. 52 2019).

Many in-situ and ex-situ methods for removing metals from contaminated soil have been

54 developed, including chemical or electrochemical precipitation, membrane separation processes, 55 adsorption on activated carbon, reverse osmosis, and electrodialysis (Gong et al. 2018; Elleuch et 56 al. 2021). Although these techniques provide efficient soil treatment, they are frequently time57 consuming, expensive, destroy soil fertility, and are inappropriate for treating heavily 58 contaminated soils (Liu et al. 2018). To avoid excessive accumulation of $\mathrm{Zn}$ in plants in 59 contaminated areas, and thus in the food chain, soil remediation technologies such as phytoremediation, which are both inexpensive and least invasive to the environment, must be used

61 (Yahaghi et al. 2019). Phytoremediation is a low-cost and environmentally friendly reclamation 62 method that employs plant species that can absorb and accumulate metals in their vegetative tissue 63 (Liu et al. 2018). The effectiveness of this technique is directly related to plants' ability to 64 accumulate metal and produce biomass (Sarwar et al., 2017; Napoli et al. 2019). Cultivated plants 65 exhibit varying degrees of tolerance to $\mathrm{Zn}$ deficiency or toxicity, depending on climatic and 66 edaphic factors, plant species, exposure time, and metal concentration in the soil (Grassi et al. 67 2020).

Crop plant remediation and reclamation of $\mathrm{Zn}$-contaminated soils may pose a serious threat 69 to food safety and thus human health (Ramakrishna and Rao 2013; Sidhu et al. 2020). Thus, the 70 reclamation and restoration of $\mathrm{Zn}$-contaminated soils through the use of $\mathrm{BCP}$ is critical. Besides, 71 it is essential to incorporate $\mathrm{BCP}$ with phytoremediation to achieve low-cost soil removal of 
72 contaminants through biodiesel production. In this context, the current study was conducted to to:

73 i) assess the phytoremediation efficiency and tolerance of six investigated BCP: Zea mays (maize,

74 hybrid 360), Z. mays (maize, hybrid 123), Helianthus annus (sunflower), Brassica juncea (indian

75 mustard), Ricinus communis (castor oil), Simmondsia chinensis (jojoba) grown in Zn-

76 contaminated soil, ii) estimate the concentration of $\mathrm{Zn}$ in the different plant organs and its impact

77 on the morphological and growth metrics of the target plants. The outcome of this work is expected

78 to afford an insight for using tested oil crop plants and detecting the most promising species in

79 restroration of $\mathrm{Zn}$-polluted soils.

80 Materials and Methods

81 Plant materials

82 Seeds of Zea mays (trihybrid 360), Zea mays (trihybrid 123), Helianthus annus, Brassica

83 juncea, Ricinus communis, Simmondsia chinensis were identified and obtained from Agricultural

84 Research Center (ARC), Giza, Egypt. Voucher specimens of the study harvested plants were

85 identified by the authors and deposited in Umm Al-Qura University Herbarium, Makkah, Saudi

86 Arabia.

87 Experimental design

A pot experiment was carried out from November 2018 to March 2019 in the greenhouse

89 of the Faculty of Applied Science, Umm Al-Qura University, Saudi Arabia (21 ${ }^{\circ} 18^{\prime} 56.3^{\prime \prime} \mathrm{N}$

$\left.9039^{\circ} 56^{\prime} 47.8^{\prime \prime} \mathrm{E}\right)$. The greenhouse settings were set at $20-28^{\circ} \mathrm{C}$ temperatures and $50.0 \pm 4.0 \%$ relative

91 humidity. The experiment was designed to assess Zn-uptake by six BCP cultivated in Zn-polluted

92 soil. The soil was collected from cultivated fields and sands (2:1) from the neighborhood, air dried,

93 sieved, and homogenized. This soil was characterized by $7.75 \mathrm{pH}$, and $420.0 \mu \mathrm{S} \mathrm{cm}^{-1}$ electrical

94 conductivity (EC). The total and DTPA-Zn (available) background levels were $35.6 \pm 3.5$ and

$9520.7 \pm 5.8 \mathrm{mg} \mathrm{kg}^{-1}$, respectively. Five different treatments of $\mathrm{Zn}$ as zinc sulphate $\left(\mathrm{ZnSO}_{4}-7 \mathrm{H}_{2} \mathrm{O}\right)$ 


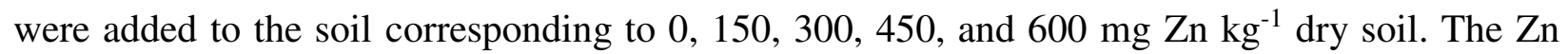
levels of 450 and $600 \mathrm{mg} \mathrm{kg}^{-1}$ were selected depending on the phytotoxicity threshold documented by Alloway (2008). The treated soil was equilibrated for about 30 days, and then used in the experiment. The experiment used a randomized complete block design with 180 pots ( 6 crop plants, 5 treatments, and 6 replicates). Each pot (30 $\mathrm{cm}$ in diameter and $35 \mathrm{~cm}$ in height) was filled with $17 \mathrm{~kg}$ soil, and 5 grains/seeds of each plant were sown in each pot and left to grow in the greenhouse under natural day/light conditions for 100 days. After 50 days of sowing, the pots were drip irrigated twice a week, and the plants were thinned to 2 plants per pot (R. communis and $S$. chinensis) and 3 plants per pot (Z. mays T360 and T123, H. annus, and B. juncea), while the emerged weeds were manually weeded.

\section{Growth measurements}

After 100 days from sowing, the investigated crop plants were harvested, and separated into stem, leaves, floral disk (H. annus)/pod (B. juncea)/cob (Z. mays), and seeds/grains. The shoot and root length was measured for each plant, in addition to the cope length of $Z$. mays and floral disc diameter of H. annus were also measured. Moreover, the different parts of each plant were weighed before and after oven-drying at $65^{\circ} \mathrm{C}$ till constant weight to determine their fresh and dry weight (g/plant), respectively.

\section{Plant analysis}

Three samples from each harvested plant part from each treatment ( $n=60$ for $Z$. mays, $H$. annus and B. juncea, and $n=30$ for $R$. communis and S. chinensis) were collected, oven-dried (at $65^{\circ} \mathrm{C}$ ), grinded in a metal-free plastic mill for homogeniety, and sieved through a $2 \mathrm{~mm}$ mesh. To determine Zn concentration (Allen 1989), a $1 \mathrm{~g}$ ground sample was digested with a $20 \mathrm{ml}$ tri-acid mixture of $\mathrm{HNO}_{3}: \mathrm{H}_{2} \mathrm{SO}_{4}: \mathrm{HClO}_{4}(5: 1: 1, \mathrm{v} / \mathrm{v} / \mathrm{v})$ to determine $\mathrm{Zn}$ concentration using an atomic absorption spectrophotometer (Shimadzu AA-6300; Shimadzu Co. Ltd., Japan). 


\section{Soil analysis}

Three soil samples collected prior to crop plant cultivation were air-dried and sieved through a $2 \mathrm{~mm}$ sieve. $1 / 5(\mathrm{w} / \mathrm{v})$ soil water extracts were prepared to determine $\mathrm{pH}$ with a $\mathrm{pH}$ meer Model 9107 BN, ORION type, and electrical conductivity (EC) with a conductivity meter 60 Sensor Operating Instruction Corning. Furthermore, the total Zn content of soil samples collected prior to cultivation was estimated using plant analysis procedures. According to Lindsay and Norvell (1978), the available Zn concentration of soil before and after harvesting of each plant (in each treatment) was extracted and measured using DTPA (diethylene triamine pentaacetate).

\section{Data analysis}

\section{Tolerance index $(T I)$}

The tolerance index (TI) of the six tested BCP to $\mathrm{Zn}$ was assessed based on the growth measurements, including root and shoot length and biomass. It was estimated according to the equation of $\mathrm{Wu}$ et al. (2018):

$\mathrm{TI}=$ morphological measurement in each Zn-treatment/morphological measurement in the control soil

\section{Zn-uptake}

The bioaccumulation factor $(\mathrm{BF})$ is an appropriate method for modeling heavy metal uptake from soil to plant root, whereas the translocation factor (TF) evaluates heavy metal transfer from root to various plant aerial parts. They were calculated to determine the ability of the plants studied to absorb Zn from the soil and transport it to their shoots (Ghosh and Singh 2005). According to Galal et al. (2021a), it was calculated as follows:

$$
\mathrm{BF}=\mathrm{C}_{\text {root }} / \mathrm{C}_{\text {soil }}
$$

$$
\mathrm{TF}_{\text {shoot }}=\mathrm{C}_{\text {shoot }} / \mathrm{C}_{\text {root }}
$$

$$
\mathrm{TF}_{\text {grain } / \text { seed }}=\mathrm{C}_{\text {grain } / \text { seed }} / \mathrm{C}_{\text {root }}
$$


144 Where, $\mathrm{C}_{\text {soil }}, \mathrm{C}_{\text {root }}, \mathrm{C}_{\text {shoot}}$, and $\mathrm{C}_{\text {grain/seed }}$ are the $\mathrm{Zn}$ concentration $\left(\mathrm{mg} \mathrm{kg}^{-1}\right)$ in the soil, root, stem, 145 and grain/seed, respectively.

\section{$146 \quad$ Phytoremediation efficiency $(P E)$}

The phytoremediation efficiency of a plant, which investigates the potential of this plant to remove a heavy metal from contaminated soil, was estimated according to Yuana et al (2019):

$$
\text { Phytoremediation efficiency }(\%)=\frac{\mathrm{C} 1-\mathrm{C} 2}{\mathrm{C} 1} \times 100
$$

where $C_{1}$ and $C_{2}$ are the concentrations of $\mathrm{Zn}\left(\mathrm{mg} \mathrm{kg}^{-1}\right)$ of the soil before cultivation and after

151 harvesting for each plant, respectively.

\section{Statistical analysis}

Before performing analysis of variance (ANOVA), the data of plant variables and $\mathrm{Zn}$ treatment parameters were checked for normality of distribution and homogeneity of variance, and data were log-transformed as needed. The significance of variation in $\mathrm{Zn}$-concentration in the

156 different organs of the different study BCP was tested using two-way ANOVA. To assess the 157 relationship between the Zn-tolerance index of the plants' growth measurements and the 158 bioaccumulation criteria, including $\mathrm{Zn}$ concentration and the bioaccumulation factor, the simple 159 linear correlation coefficient (r) was calculated. SPSS software was used for all statistical analyses 160 (SPSS 2012).

\section{Results}

\section{Soil Zn-content}

The application of Zn-treatments $\left(0,150,300,450,600 \mathrm{mg} \mathrm{kg}^{-1}\right)$ for the soil supporting 164 the growth of the six BCP led to soil available Zn contents of 20.7, 58.73, 102.82, 130.24, and $165185.95 \mathrm{mg} \mathrm{kg}^{-1}$ (Table 1). After plant harvesting, the $\mathrm{Zn}$ content of the soil supporting the growth 166 of each plant was significantly reduced $(p<0.05)$. Compared to the soil Zn-contents before 
167 cultivation, the soil of $R$. communis had the highest contents $\left(19.9\right.$ and $\left.88.5 \mathrm{mg} \mathrm{kg}^{-1}\right)$ at the control 168 and $300 \mathrm{mg} \mathrm{kg}^{-1} \mathrm{Zn}$-treatment; respectively, while that of Z. mays T123 had the lowest (19.9 and $16988.5 \mathrm{mg} \mathrm{kg}-1)$. Besides, the soil of $S$. chinensis `recorded the highest Zn contents (108.9 and 151.8 $170 \mathrm{mg} \mathrm{kg}-1$, while that of $Z$. mays T360 had the lowest $\left(84.3\right.$ and $\left.112.4 \mathrm{mg} \mathrm{kg}^{-1}\right)$ at 450 and $600 \mathrm{mg}$ $171 \mathrm{~kg}^{-1}$, respectively. Moreover, the soil of $H$. annus had the highest content $\left(53.4 \mathrm{mg} \mathrm{kg}^{-1}\right)$, while 172 that of $B$. juncea had the lowest $\left(37.5 \mathrm{mg} \mathrm{kg}^{-1}\right)$ at $150 \mathrm{mg} \mathrm{kg}^{-1} \mathrm{Zn}$-treatment compare to their 173 corresponding soil before cultivation.

\section{$174 \quad$ Effect of Zn-treatments on the morphological traits}

The present results indicated that the morphological traits of the six study bioenergy crop

176 plant BCP s significantly increased to a certain limit and then significantly declined by increasing 177 Zn concentration in the soil (Fig. 1). It was found that Z. mays T123, H. annus, B. juncea, R. 178 communis, and $S$. chinensis had their maximum root length $(26.0,7.3,10.9,37.0$ and $15.9 \mathrm{~cm}$, 179 respectively) at $150 \mathrm{mg} \mathrm{kg}^{-1} \mathrm{Zn}$-treatment, while $Z$. mays $\mathrm{T} 360$ attained its longest root $(31.0 \mathrm{~cm})$ 180 at $300 \mathrm{mg} \mathrm{kg}^{-1}$. Besides, Z. mays T123, B. juncea, and S. chinensis had their highest shoot lengths $181 \quad(129.3,105.7$ and $30.1 \mathrm{~cm})$ at $150 \mathrm{mg} \mathrm{kg}^{-1}$, while Z. mays T360 and H. annus attained their highest 182 shoot lengths $(216.0$ and $146.3 \mathrm{~cm})$ at $300 \mathrm{mg} \mathrm{kg}^{-1}$, and $R$. communis $(90.7 \mathrm{~cm})$ at $450 \mathrm{mg} \mathrm{kg}^{-1} \mathrm{Zn}^{-}$ 183 treatment. Moreover, the six BCP showed the minimum root and shoot lengths at $600 \mathrm{mg} \mathrm{kg}^{-1} \mathrm{Zn}^{-}$ 184 treatment. Furthermore, the highest cob length $(18.1$ and $10.8 \mathrm{~cm})$ for Z. mays T360 and Z. mays 185 T123, respectively as well as the disk diameter $(8.7 \mathrm{~cm})$ for $H$. annus were recorded at $150 \mathrm{mg}$ $186 \mathrm{~kg}^{-1}$, while the lowest $(10.8,7.3$ and $6.5 \mathrm{~cm})$, respectively was recorded aat $600 \mathrm{mg} \mathrm{kg}^{-1} \mathrm{Zn}^{-}$ 187 treatment. 
The data of plant weight of the study BCP organs under different Zn-treatments showed

190

that $150 \mathrm{mg} \mathrm{kg}^{-1} \mathrm{Zn}$ content in the soil was the most flourishing for these plants except the root weight of $S$. chinensis, which had its highest fresh (FW) and dry (DW) root weight (0.99 and 0.33 g plant ${ }^{-1}$ ) in the control soil (Fig. 2). However, most of the measured growth criteria had their minimum values in soil contaminated with $600 \mathrm{mg} \mathrm{kg}^{-1} \mathrm{Zn}$, except $R$. communis root and shoot DW (4.1 and $27.8 \mathrm{~g} \mathrm{plant}^{-1}$ ) at 450 and $0 \mathrm{mg} \mathrm{kg}^{-1} \mathrm{Zn}$-treatement, respectively. Z. mays T360, Z. mays T123, H. annus, and B. juncea had their highest root FW (12.9, 8.7, 4.4 and $\left.0.5 \mathrm{~g} \mathrm{plant}^{-1}\right)$, root DW (4.1, 6.6, 2.1, and 0.1 $\left.\mathrm{g} \mathrm{plant}^{-1}\right)$, shoot FW (71.4, 106.3, 571 and $\left.14.3 \mathrm{~g} \mathrm{plant}^{-1}\right)$, and shoot DW (23.9, 28.7, 9.7 and $\left.3.6 \mathrm{~g} \mathrm{plant}^{-1}\right)$ in $150 \mathrm{mg} \mathrm{kg}^{-1}$ Zn-treated soil. Likewise, Z. mays T360, Z. mays T123, and B. juncea attained their highest cope/pod FW (16.0, 16.2, and 5.9 g plant $^{-1}$ ), and DW $\left(9.1,5.7\right.$, and $\left.4.2 \mathrm{~g} \mathrm{plant}^{-1}\right)$ at $150 \mathrm{mg} \mathrm{kg}^{-1}$, while the lowest $\left(8.0,7.9\right.$, and $\left.2.5 \mathrm{~g} \mathrm{plant}^{-1}\right)$ and $\left(2.4,1.9\right.$, and $\left.1.5 \mathrm{~g} \mathrm{plant}^{-1}\right)$ was at $600 \mathrm{mg} \mathrm{kg}^{-1} \mathrm{Zn}$-treatment. At the same treatments, Z. mays T360, Z. mays T123, H. annus, and B. juncea reached it maximum $\left(30.5,29.1,8.7\right.$, and 0.5 g plant $^{-}$ $\left.{ }^{1}\right)$ and minimum $\left(19.1,18.3,6.5\right.$, and 0.4 g plant $\left.^{-1}\right) 100$ seeds weight.

\section{Tolerance index $(\mathrm{TI})$}

The investigated BCP, except $S$. chinensis root DW, can tolerate $150 \mathrm{mg} \mathrm{kg}^{-1} \mathrm{Zn}$ content of the soil, where they had TI greater than 1 for all growth criteria (Table, 2). Besides, some species can tolerate higher soil Zn content such as Z. mays T360 root and shoot length and shoot weight; and Z. mays T123 root DW; R. communis root length; and S. chinensis shoot length can tolerate $300 \mathrm{mg} \mathrm{kg}^{-1} \mathrm{Zn}$ contents; and $B$. juncea root length can tolerate $450 \mathrm{mg} \mathrm{kg}^{-1}$, and its shoot length and root DW can tolerate $300 \mathrm{mg} \mathrm{kg}^{-1}$. Moreover, $H$. annus had high potential to tolerate Zn-contaminated soils with the highest TI $(1.84,1.79,1.60$ and 1.49), which decreased with increasing Zn contents compared with the other investigated species. It is worth noting that Z. mays 
212 T123 and R. communis were the most susceptible plants, while B. juncea and S. chinensis were 213 moderately tolerant and $H$. annus was the most tolerant to high $\mathrm{Zn}$-concentrations.

\section{Plants Zn-concentration}

The two-was analysis of variance (ANOVA II) of the $\mathrm{Zn}$ concentrations in the different plants' tissues (root, shoot, cope/floral disc/pod, and seeds/grains) indicated significant variations

$217(p<0.05)$ in the accumulation potential of the different plants, Zn-treatments, and their intercept

218 (Table 3). It was clear that increasing the soil Zn-content led to a significant $(p<0.05)$ increase 219 in the concentration of $\mathrm{Zn}$ in the different tissues of the six BCP. Whereas, the least $\mathrm{Zn}$ 220 concentration was obtained at the control soil, while the highest was at $600 \mathrm{mg} \mathrm{kg}^{-1} \mathrm{Zn}$-treatment 221 for all plant tissues, except $H$. annus shoot, which attained its highest content $\left(227.8 \mathrm{mg} \mathrm{kg}^{-1}\right)$ at $222450 \mathrm{mg} \mathrm{kg}^{-1} \mathrm{Zn}$-treatment. Regarding the plant species grown at $600 \mathrm{mg} \mathrm{kg}^{-1} \mathrm{Zn}$ treated soil, $Z$ 223. mays T123 accumulated significantly $(p<0.05)$ the highest concentrations of $\mathrm{Zn}(458.95,464.20$, 224 209.85, and $233.00 \mathrm{mg} \mathrm{kg}^{-1}$ ) in its root, shoot, grains and cope, respectively. On the other hand, 225 B. juncea had the lowest $\mathrm{Zn}$ concentration $\left(227.34\right.$ and $\left.130.90 \mathrm{mg} \mathrm{kg}^{-1}\right)$ in its root and seeds; 226 respectively, $R$. communis (199.36 $\left.\mathrm{mg} \mathrm{kg}^{-1}\right)$ in its shoot, and H. annus $\left(173.95 \mathrm{mg} \mathrm{kg}^{-1}\right)$ in its floral 227 disk.

\section{Zn uptake}

The statistical analysis (ANOVA II) indicated a significant variation in the BF of $\mathrm{Zn}$ from 230 soil to plants' root, and the TF from root to shoot and from root to grains/seeds among the 231 investigated plants grown under different Zn-treatments (Table 4). The six study plants showed 232 potential accumulation of $\mathrm{Zn}$ from the soil to their root with $\mathrm{BF}_{\text {root }}$ greater than 1 at each $\mathrm{Zn}$ treatment, except at the control soil for Z. mays T123, B. juncea, $R$. communis, and $S$. chinensis, where their BF did not exceed 1. The highest BF (2.84) was recorded for Z. mays T123 at $450 \mathrm{mg}$ 
$235 \mathrm{~kg}^{-1} \mathrm{Zn}$-treatment. On the other side, $R$. communis showed low transfer of $\mathrm{Zn}$ from its root to the 236 shoot at all Zn-treatments, while B. juncea at all treatments except $300 \mathrm{mg} \mathrm{kg}^{-1}$, with $\mathrm{TF}_{\text {shoot }}$ greater

237 than 1. Besides, Z. mays T360, Z. mays T123, and B. juncea showed translocation of Zn from root 238 to shoot at the control treatment $\left(\mathrm{TF}_{\text {shoot }}=1.43,1.40\right.$, and 1.22$)$ and $150 \mathrm{mg} \mathrm{kg}^{-1}\left(\mathrm{TF}_{\text {shoot }}=1.03,1.62\right.$ 239 and 1.52), respectively. In addition, $H$. annus had $\mathrm{TF}_{\text {shoot }}(1.03)$ at the control treatment, while $R$. 240 communis and $S$. chinensis did not transfer $\mathrm{Zn}$ from the root to the shoot with $\mathrm{TF}_{\text {shoot }}$ less than 1. 241 The highest $\mathrm{TF}_{\text {shoot }}$ (1.62) was recorded for $Z$. mays $\mathrm{T} 123$ at $150 \mathrm{mg} \mathrm{kg}^{-1} \mathrm{Zn}$-treatment. 242 Furthermore, the transfer of $\mathrm{Zn}$ from the root to the plants' grains/seeds indicated that the study $243 \mathrm{BCP}$ did not translocate this element to their grains/seeds with $\mathrm{TF}_{\text {grain/seed }}$ less than 1 at all $\mathrm{Zn}$ 244 treatment.

245 Phytoremediation efficiency (PE)

The phytoremediation efficiency of the study BCP showed significant variation $(p<0.05)$

247 at the different Zn-treatments and the intercept between plants and treatments (Fig. 3). The PE of 248 Z. mays T360, and R. communis increased with the increasing Zn content in the soil from 8.6\% 249 and $3.2 \%$ at the control treatment to reach its maximum (39.4\% and $24.9 \%)$ at $450 \mathrm{mg} \mathrm{kg}^{-1}$, and 250 then started to decrease (37.5 and 22.0\%) at $600 \mathrm{mg} \mathrm{kg}^{-1} \mathrm{Zn}$-treatment, respectively. Besides, the 251 PE of Z. mays T123 and H. annus ranged between $24.7 \%$ and $9.1 \%$ at $150 \mathrm{mg} \mathrm{kg}^{-1}$ and $33.3 \%$ and $252 \quad 28.6 \%$ at $450 \mathrm{mg} \mathrm{kg}^{-1}$; respectively. However, B. juncea and S. chinensis had their maximum PE 253 (36.0 and 24.1\%) at $150 \mathrm{mg} \mathrm{kg}^{-1}$, while the lowest (27.5 and 15.5\%) at the control and $600 \mathrm{mg} \mathrm{kg}^{-}$

$254{ }^{1}$ Zn-treatments, respectively. It is worth to note that Z. mays T360 had the highest PE, while $R$. 255 communis had the lowest to remove $\mathrm{Zn}$ metal from $\mathrm{Zn}$-contaminated soils. On the average, the six 256 study BCP were arranged according to their PE as follow: B. juncea (31.9\%) > Z. mays T123 
$(31.1 \%)>$ Z. mays $\mathrm{T} 360(27.6 \%)>H$. annus $(20.8 \%)>S$. chinensis $(20.3 \%)>R$. communis $258(15.3 \%)$.

\section{Correlation analysis}

The simple linear correlation coefficient between the Zn-tolerance index and the bioaccumulation characteristics of the six BCP (Table 5) indicated that the TI of the root and shoot length and root and shoot weight was negatively correlated with root $\mathrm{Zn}$ content $(\mathrm{r}=-0.618$, 0.723, -573, and -0.722), shoot Zn-contents ( $\mathrm{r}=-0.483,-0.666,-0.362$, and -0.787$)$. Besides, the

264 shoot length TI was negatively correlated $(r=-0.257)$ with the bioaccumulation of $\mathrm{Zn}$ from soil 265 to the root. On the other hand, The TF of $\mathrm{Zn}$ from root to shoot was significantly proportional to 266 the TI of the root length and root weight ( $\mathrm{r}=0.258$ and 0.439 , respectively).

267 Discussion

268 Soil properties

Zinc is a significant ecotoxic metal that pollutes both the terrestrial and aquatic environments (Elleuch et al. 2021). The total soil Zn content used in the present investigation was

$27135.6 \mathrm{mg} \mathrm{kg}^{-1}$, which did not exceed the range (50-55 and 10-100 mg kg-1) reported by Kiekens 272 (1995) and Mertens and Smolders (2013), respectively for normal soils. Besides, Kabata-Pendias 273 and Pendias (2001) reported $\mathrm{Zn}$ content (47-61 $\mathrm{mg} / \mathrm{kg})$ in natural medium loamy soil such as that 274 used in the present study. Therefore, the soil used in the present investigation was Zn275 uncontaminated, but after treatments it became $\mathrm{Zn}$-contaminated. Moreover, available $\mathrm{Zn}$ to plants 276 is affected by the total $\mathrm{Zn}$ content, $\mathrm{pH}$, concentrations of other heavy metals, and macro-nutrients 277 (Alloway 2008). In the present study, the available $\mathrm{Zn}$ of the soil, before ethe experiment, ranged 278 between 20.7 and $185.9 \mathrm{mg} \mathrm{kg}^{-1}$ at the control and $600 \mathrm{mg} \mathrm{kg}^{-1} \mathrm{Zn}$-treatment, respectively of the 279 slightly alkaline soil $(\mathrm{pH}=7.75)$. According to Al-Sodany et al. (2022), slightly alkaline $\mathrm{pH}$ may 280 limit metal availability and solubility in the soil, besides Liu et al. (2020) reported that soils with 
281 a $\mathrm{pH}>7.4$ have relatively low available $\mathrm{Zn}$ content because the solubility of $\mathrm{Zn}$ decreases with 282 increasing $\mathrm{pH}$.

283

284

285

286

287

288

289

290

291

292

293

294

295

296

297

298

299

300

301

302

303

304

\section{Plant Growth}

Zinc is an essential trace element for proper plant growth and reproduction and plays an important role in many biological processes (Cakmak 2008, Noulas et al. 2018). The investigated BCP showed the highest root, shoot length, and cope/floral disc at $150 \mathrm{mg} \mathrm{kg}^{-1} \mathrm{Zn}$-treatment, except Z. mays T360 root and shoot, and H. annus shoot, which attained their highest values at $300 \mathrm{mg} \mathrm{kg}^{-1}$, and $R$. communis shoot length at $450 \mathrm{mg} \mathrm{kg}^{-1} \mathrm{Zn}$-treatment. In the same context, Sidhu et al. (2020) reported that when treated with 100, $250 \mathrm{mg} \mathrm{kg}^{-1} \mathrm{Zn}$ regimes, the root and shoot length of Coronopus didymus increased compared to the control. The six BCP, on the other hand, had the smallest morphological measurements after $600 \mathrm{mg} \mathrm{kg}^{-1} \mathrm{Zn}$ treatment. Owing to Galal et al. (2021b), heavy metals, including Zn, induce a number of morphological and physiological changes that inhibit the growth of most plant species. Several studies, including Farahat et al. (2017) on wheat and maize, Ahmed and Slima (2018) on jew's mallow, Galal et al. (2018) on cabbage, Shehata and Galal (2020) on cucumbers, Galal et al. (2021c) on castor oil, Galal et al. (2021a) on garden pea, and Ahmed et al. (2021) on okra plant, have reported decreased plant growth parameters like root and shoot length, plant biomass and production, in contaminated soils with heavy metals including Zn.

Zinc is required in small but critical concentrations for plant growth, and if available amounts are insufficient, plants will suffer from physiological stress caused by the dysfunction of several enzyme systems and other metabolic functions that require Zn (Alloway 2008). The study BCP organs showed that $150 \mathrm{mg} \mathrm{kg}^{-1}$ soil Zn-treatment was the most flourishing for all plants except the root weight of $S$. chinensis, which had its highest fresh (FW) and dry (DW) weight in the control soil. In a similar study, Sidhu et al. (2020) discovered that a moderate Zn supply (100 
$305-250 \mathrm{mg} \mathrm{kg}^{-1}$ ) in the soil increased $C$. didymus growth, whereas a $500 \mathrm{mg} \mathrm{kg}^{-1} \mathrm{Zn}$ regime reduced 306 growth and biomass in comparison to the control plants. According to the current findings, the 307 different organs of $B$. juncea reached their maximum weight at $150 \mathrm{mg} \mathrm{kg}^{-1} \mathrm{Zn}$ treatment and were 308 then negatively affected $(p<0.05)$ by increasing soil $\mathrm{Zn}$ content. These findings were consistent 309 with the those of Ebbs and Kochian (1998) and Grassi et al. (2020), who found that the highest 310 DW of B. juncea was found in the control and then decreased as $\mathrm{Zn}$ content in the soil increased, 311 indicating that $\mathrm{Zn}$ has a negative effect on the plant growth. Furthermore, Ashraf et al. (2019) 312 observed on $H$. annuus plants that a low or moderate heavy metal dose can facilitate plant growth. 313 The majority of the measured growth criteria, on the other hand, had their minimum values 314 in soil contaminated with $600 \mathrm{mg} \mathrm{kg}^{-1} \mathrm{Zn}$, with the exception of $R$. communis root DW at $450 \mathrm{mg}$ $315 \mathrm{~kg}^{-1} \mathrm{Zn}$-treatment. Excessive $\mathrm{Zn}$ application, according to Jin et al. (2008) and Michael and 316 Krishnaswamy (2011), usually inhibits growth in non-hyperaccumulating plants such as Sedum 317 alfredii and Phaseolus vulgaris, respectively. Grassi et al. (2020) discovered that the FW and DW 318 of $R$. communis shoots and roots did not increase significantly $(p<0.05)$ with increasing soil $\mathrm{Zn}$ 319 concentrations, which is consistent with the current study. Furthermore, Wang et al. (2016) 320 discovered that increasing soil $\mathrm{Zn}$ concentrations up to $400 \mathrm{mg} \mathrm{kg}^{-1}$ increased $R$. communis 321 biomass, whereas $\mathrm{Zn}$ concentrations greater than $600 \mathrm{mg} \mathrm{kg}^{-1}$ reduced plant growth in comparison 322 to the control. Furthermore, Yadav et al. (2009) and Grassi et al. (2020) reported that soil $\mathrm{Zn}$ 323 enhanced the growth of Jatropha curcas, a Euphorbiaceous species related to R. communis, up to $3241000 \mathrm{mg} \mathrm{kg}^{-1}$, while higher $\mathrm{Zn}$ concentrations stunted plant growth. One reason for decreased 325 growth and biomass is likely due to excess $\mathrm{Zn}$ interfering with vital metabolic activities in plants 326 (Michael and Krishnaswamy 2011) and nutrient uptake (Sidhu, 2016; Sidhu et al. 2020).

\section{Plant-tolerance to Zn-treatments}


329 Zn-efficient plants are able to produce more biomass and production under conditions of low available Zn supply than Zn-inefficient plants (Alloway 2008). The present investigation revealed that Z. mays T123 and R. communis were the most susceptible plants, while $B$. juncea and $S$. chinensis were moderately tolerant and H. annus was the most tolerant to high Zn-concentrations.

333 Shi and Cai (2010) discovered, on the other hand, that among the eight studied species, H. annus 334 did not grow well under Zn stress (400-800 $\left.\mathrm{mg} \mathrm{kg}^{-1}\right)$. Brassica species have been reported by some 335 authors (e.g., Barrameda-Medina et al., 2014; Mourato et al., 2015) to be accumulator plants with 336 high tolerance to heavy metals in soils. Barrameda-Medina et al. (2014) also described an increase 337 in $\mathrm{Zn}$ in leaves and stems as a result of $B$. oleracea's tolerance mechanism when grown 338 hydroponically in Zn-spiked solution. Furthermore, plant roots were more resistant to $\mathrm{Zn}$ stress 339 than shoots, which could be attributed to a reduction in $\mathrm{Zn}$ translocation to the aerial parts (Kabata340 Pendias and Pendias, 2001); or, more likely, to the development of mechanisms such as cellular 341 compartmentalisation in the roots, enhancing plant resistance to metal stress (Leitenmaier and 342 Küpper 2013).

\section{Zn uptake by plants}

Zinc accumulation in the different organs of the six BCP was dose-dependent since $\mathrm{Zn}$ concentration increased in the plant tissues in response to its increase in the soil. Similar results were reported by Wang et al. (2016), Akanbi-Gada et al. (2019) and Grassi et al. (2020), who

347 found that the $\mathrm{Zn}$ concentration in Solanum lycopersicum and B. juncea plant tissues increased 348 considerably $(p<0.05)$ compared to the control as the soil $\mathrm{Zn}$-content increased. Furthermore, 349 Hernandez-Viezcas et al. (2013) discovered dose-dependent $\mathrm{Zn}$ accumulation in soybean treated 350 with various $\mathrm{Zn}$ concentrations. The root accumulated more $\mathrm{Zn}$ concentrations than the shoots in 
351 the majority of the plants studied (except B. juncea). This finding was consistent with the findings

352 of Liu et al. (2015), Jahan et al. (2018), and Akanbi-Gada et al. (2019), who attributed the low Zn

353 translocation to shoots to Zn's ability to effectively bind to root tissues, or possibly due to the

354 plant's exclusion strategy to avoid Zn toxicity. Similarly, Zhao et al. (2012) and Mukherjee et al.

355 (2013) found similar low $\mathrm{Zn}$ translocation from the root to the shoot of maize and green pea plants.

356 Grassi et al. (2020) discovered no significant difference in $\mathrm{Zn}$ accumulation in the roots and shoots

357 of B. juncea. According to Marschner (1995), most plants have $\mathrm{Zn}$ concentrations ranging from

35830 to $100 \mathrm{mg} \mathrm{kg}-1$, with concentrations above $300 \mathrm{mg} \mathrm{kg}^{-1}$ considered toxic. As a result, the $\mathrm{Zn}$

359 concentrations in the above-ground parts of the investigated BCP (with the exception of Z. mays

$360 \mathrm{~T} 123$ and $B$. juncea at $600 \mathrm{mg} \mathrm{kg}^{-1} \mathrm{Zn}$-treatment) were within the safe range.

361 Zn uptake

362

The BF exemplifies a plant species' ability to collect elements from the soil, and thus the

363 properties of phytoremediation (Al-Sodany et al. 2022). It was reported that the amount of 364 available metal in the soil influenced the transfer of heavy metals from soil to root (Li et al. 2022).

365 The study BCP showed potential accumulation of $\mathrm{Zn}$ from the soil to their root with $\mathrm{BF}$ greater

366 than 1 at each Zn-treatment, except at the control soil for Z. mays T123, B. juncea, R. communis,

367 and S. chinensis, where their BF did not exceed 1. However, Grassi et al. (2020) found that the

368 estimated $\mathrm{BF}$ value was $<1$ for $R$. communis plants cultivated in $\mathrm{Zn}$-spiked soil, while that

369 cultivated in control was $>1$. In addition, $B$. juncea showed transfer of $\mathrm{Zn}$ from its root to the shoot

370 at all $\mathrm{Zn}$-treatments, except $300 \mathrm{mg} \mathrm{kg}^{-1}$ with $\mathrm{TF}_{\text {shoot }}$ higher than 1 . Meanwhile, R. communis and

371 S. chinensis showed low transfer of $\mathrm{Zn}$ from their root to the shoot at all $\mathrm{Zn}$-treatments. According

372 to Kabata-Pendias and Pendias (2001), high Zn content in the soil facilitates its translocation from

373 the roots to the shoots, resulting in high $\mathrm{Zn}$ acclimatisation in the shoots, which corresponds to 
greater $\mathrm{Zn}$ phytoextraction potential of $B$. juncea. This species has been considered a $\mathrm{Zn}$-tolerant plant species capable of absorping and translocating high $\mathrm{Zn}$ amounts in their tissues from high soil Zn content. Controversily, Grassi et al. (2020) recorded that the estimated BF and TF values for $B$. juncea and the TF for $R$. communis were less than 1 for the $\mathrm{Zn}$-spiked soil suggesting the potential of these species in phytostabilization. Moreover, Z. mays T360 and Z. mays T123 above $150 \mathrm{mg} \mathrm{kg}^{-1}$, and $H$. annus above the control Zn-treatments had TF less than 1, suggesting their potential suitability for Zn phytostabilization. Similar results were suggested by Farahat et al. (2017) on Z. mays crop plants. It is worth to note that the study BCP did not translocate this element to their grains/seeds. Consequently, these species can be used safely in phytoremediation of $\mathrm{Zn}$ from Zn-contaminated soils.

\section{Tolerance index-bioaccumulation characteristics correlations}

The simple linear correlation coefficient between the $\mathrm{Zn}$-tolerance index and the bioaccumulation characteristics of the six $\mathrm{BCP}$ indicated that the TI of the root and shoot length and root and shoot weight was negatively correlated with root and shoot $\mathrm{Zn}$ content. Our results coincided with those of Shi and Cai (2010), who recorded TI values with significant negatively correlation with the $\mathrm{Zn}$ concentration in the roots and shoots of some crop plants. They showed that the high $\mathrm{Zn}$ tolerance of hemp, flax, and rapeseed was due to lower $\mathrm{Zn}$ concentrations in the shoots due to the use of the exclusion strategy. On the other side, the TF of $\mathrm{Zn}$ from root to shoot was significantly proportional to the TI of the root length and root weight. Hamilton et al. (1993) and Han et al. (2011) discovered that soil DTPA-extractable Zn had a positive correlation with crop uptake in similar conditions, implying that it could be used as a reliable index for predicting Zn availability in high pH soils. Furthermore, Liu et al. (2020) discovered a strong relationship between soil DTPA-extractable Zn and Zn uptake by soybean and wheat. 


\section{Phytoremediation efficiency}

The PE is determined by the amount of metal uptake from the contaminated soil by the plant tissues (Shi and Cai 2010). The ability of plants to extract large amounts of heavy metals from soil is critical to the development of phytoremediation technology (Yang et al. 2017; Zou et al. 2021). The $\mathrm{Zn}$ content of the soil supporting the growth of the six BCP was significantly reduced $(p<0.05)$ at the end of the experiment. At lower soil Zn-contents, B. juncea, and Z. mays T123 were the potential species for uptaking $\mathrm{Zn}$ from the soil, while at higher soil Zn-contents, $Z$. mays T360 was the most efficient. All tested BCP had high $\mathrm{Zn}$ concentrations in the roots and shoots, high $\mathrm{BF}$ and $\mathrm{Zn}$ uptake, and high biomass at $150-450 \mathrm{mg} \mathrm{kg}^{-1} \mathrm{Zn}$ treatments, indicating that these plants are good candidates for the implementation of our new strategy of cultivating BCP for phytoremediation in Zn-contaminated soils. Zhou et al. (2020) reported similar results on some crop plants, including H. annus. According to Shi and Cai (2010), the ideal plant for phytoextraction should be tolerant to high levels of the metal and accumulate high levels of the metal in its harvestable parts, so H. annus was a good candidate for Zn-phytoextraction. It is worth to note that Z. mays T360 had the highest efficiency, while $R$. communis had the lowest to remove $\mathrm{Zn}$ metal from $\mathrm{Zn}$-contaminated soils. On the average, the six study BCP were arranged according to their PE as follow: B. juncea $(31.9 \%)>$ Z. mays T123 (31.1\%) > Z. mays T360 (27.6\%) > H. annus $(20.8 \%)>$ S. chinensis $(20.3 \%)>R$. communis $(15.3 \%)$. Although our results revealed the phytoremediation potential of the six investigated BCP, attention should be paied when extrapolating these pot study results to the field.

\section{Conclusion}

The study BCP showed that $150 \mathrm{mg} \mathrm{kg}^{-1}$ soil $\mathrm{Zn}$-treatment was the most flourishing for all plants growth metrics, while $600 \mathrm{mg} \mathrm{kg}^{-1} \mathrm{Zn}$ was the most diminishing treatment. Z. mays T123 
420 and $R$. communis were the most susceptible plants, while $B$. juncea and $S$. chinensis were 421 moderately tolerant and H. annus was the most tolerant to high Zn-concentrations. The study BCP 422 did not translocate $\mathrm{Zn}$ to their grains/seeds, and consequently they can be used safely in $\mathrm{Zn}$

423 phytoremediation from Zn-contaminated soils. The root and shoot $\mathrm{Zn}$-content was negatively 424 correlated with the TI of the root and shoot length and weight, while the TF of Zn from root to 425 shoot was significantly proportional to the TI of the root length and weight. Z. mays T360 had the 426 highest efficiency, while $R$. communis had the lowest to remove $\mathrm{Zn}$ metal from $\mathrm{Zn}$-contaminated 427 soils. At a moderate Zn supply (150-450 mg kg-1), the tested BCP had high Zn concentrations in 428 their roots and shoots, high $\mathrm{BF}$ and $\mathrm{Zn}$ uptake potential, and high biomass, indicating that these 429 plants are good candidates for implementing our new strategy of cultivating BCP for 430 phytoremediation in $\mathrm{Zn}$-contaminated soils.

431

432

433

434

435

436

$437 \quad$ Funding

438 The authors would like to thank the Deanship of Scientific Research at Umm Al-Qura 439 University for supporting this work by Grant Code: (22UQU4331100DSR01)".

440 Author contribution Conceptualization:

441 A.Q., M.E., and H.O. Methodology: A.Q., M.E., and H.O. Analysis: A.Q., M.E., and H.O. 442 443 444
Ethics approval Not applicable.

Consent to participate Not applicable.

Consent to publish Not applicable.

Competing interests The authors declare no competing interests.
A.Q., preparation: editing:
M.E., T.G.,

M.E., H.O.and T.G. Writing-origina Writing-review draft and
T.G., M.E.,
H.O.

H.O. 
445 All authors have read and agreed to the published version of the 446 manuscript.

447

$448 \quad$ References

449

450

451

Ahmed DA, Slima DF (2018) Heavy metal accumulation by Corchorus olitorius L. irrigated with wastewater. Environ Sci Pollut Res 25:14996-15005. DOI: 10.1007/s11356-018-1675-1

452 Ahmed DA, Galal TM, Al-Yasi HM, Hassan LM, Slima DF (2021). Accumulation and 453

Akanbi-gada MA, Ogunkunle CO, Vishwakarma V, Viswanathan K, Fatoba PO 2019. translocation of eight trace metals by the different tissues of Abelmoschus esculentus Moench. irrigated with untreated wastewater. Environ. Sci. Pollut. Res. https://doi.org/10.1007/s11356-021-17315-7.

Allen SE (1989) Chemical analysis of ecological materials. Blackwell Scientific Publications, London.

Alloway BJ (2008). Zinc in soils and crop nutrition. Second edition, published by IZA and IFA Brussels, Belgium and Paris, France, 139 pp. Regression models to estimate accumulation capability of six metals by two macrophytes, Typha domingensis and Typha elephantina, grown in an arid climate in the mountainous region of Taif, Saudi Arabia. Sustainability 14, 1. https://doi.org/10.3390/su14010001 
Ashraf S, Ali Q, Ahmad Z, Ashraf S, Naeem H (2019) Phytoremediation: environmentally sustainable way for reclamation of heavy metal polluted soils. Ecotoxicology and Environmental Safety 174:714-27. doi: 10.1016/j.ecoenv.2019.02.068.

Barrameda-Medina Y, Montesinos-Pereira D, Romero L, Ruiz JM, Blasco B ( 2014). Comparative study of the toxic effect of $\mathrm{Zn}$ in Lactuca sativa and Brassica oleracea plants: I. Growth, distribution, and accumulation of Zn, and meta- bolism of carboxylates. Environ. Exp. Bot. 107, 98-104. DOI: 10.1016/j.envexpbot.2014.05.012

Bolan NS, Park JH, Robinson B, Naidu R, Huh KY (2011) Phytostabilization. A green approach to contaminant containment, Advances in Agronomy, 112, 145-204. https://doi.org/10.1016/B978-0-12-385538-1.00004

Connolly EL, Campbell NH, Grotz N, Prichard CL, Guerinot ML (2003) Overexpression of the FRO2 ferric chelate reductase confers tolerance to growth on low iron and uncovers posttranscriptional control. Plant Physiol. 133, 1102-1110.

Dmuchowski W, Gozdowski D, Bragoszewska P, Baczewska AH, Suwara I (2014) Phytoremediation of zinc contaminated soils using silver birch (Betula pendula Roth). Ecol. Eng. 71, 32-35. 11, 336; doi:10.3390/f11030336

Ebbs SD, Lasat MM, Brady DJ, Cornish J, Gordon R, Kochian LV (1997) Phytoextraction of cadmium and zinc from a contaminated soil. J. Environ. Qual. 26, 1424-1430. https://doi.org/10.2134/jeq1997.00472425002600050032x.

Elleuch J, Ben Amor F, Chaaben Z, Frikha F, Michaud P, Fendri I, Abdelka S (2021) Zinc Biosorption by Dunaliella sp. AL-1: Mechanism and Effects on Cell Metabolism. Science of the Total Environment 773:145024. 
Farahat E, Galal TM, Elawa O, Hassan L (2017) Health risk assessment and growth characteristics of wheat and maize crops irrigated with contaminated wastewater. Environ Monit Assess 189(11):535-545. https://doi.org/10.1007/s10661-017-6259-x

Galal TM, Essa B, Al-Yasi H (2021c) Heavy metals uptake and its impact on the growth dynamics of the riparian shrub Ricinus communis L. along Egyptian heterogenic habitats. Environ Sci Pollut Res. https://doi.org/10.1007/s11356-021-13383-X

Galal TM, Hassan LM, Ahmed DA, Alamri SAM, Alrumman SA, Eid EM (2021a) Heavy metals uptake by the global economic crop (Pisum sativum L.) grown in contaminated soils and its associated health risks. PLoS ONE 16(6): e0252229.

Galal TM, Khalafalla AA, Elawa OE, Hassan LM (2018) Human health risks from consuming cabbage (Brassica oleracea L. var. capitata) grown on wastewater irrigated soil. Int J Phytoremediation 20(10):1007-1016.

Galal TM, Shedeed ZA, Gharib FA, Al-Yasi HM, Mansour KH (2021b) The role of Cyperus alopecuroides Rottb. sedge in monitoring water pollution in contaminated wetlands in Egypt: a phytoremediation approach. Environ Sci Poll Res, 28:23005-23016.

Ghosh M, Singh SP (2005) A comparative study of cadmium phytoextraction by accumulator and weed species. Environ Pollut 133:365-371

Gong Y, Zhao D, Wang Q (2018) An overview of field-scale studies on remediation of soil contaminated with heavy metals and metalloids: technical progress over the last decade. Water Res. 147, 440-460. https://doi.org/10.1016/j.watres.2018.10.024.

Grassi C, Cecchi S, Baldi A, Zanchi CA, Orlandini S, Pardini A, Napoli M (2020) Crop suitability assessment in remediation of $\mathrm{Zn}$ contaminated soil. Chemosphere 246, 125706. https://doi.org/10.1016/j.chemosphere.2019.125706 
513 Hamilton MA, Westermann DT, James DW (1993) Factors affecting zinc uptake in cropping systems. Soil Sci. Soc. Am. J. 57 (5), 1310-1315.

515 516

517

Han D, Luo D, Chen Y, Wang G (2013) Transfer of Cd, Pb, and Zn to water spinach from a polluted soil amended with lime and organic materials, J. Soils Sediment. 13, 1360-1368.

Hernandez-Viezcas JA, Castillo-Michel H, Andrews JC, Cotte M, Rico C, Peralta-Videa JR, Ge Y, Priester JH, Holden PA, Gardea-Torresdey JL (2013) In Situ synchrotron X-ray fluorescence mapping and speciation of $\mathrm{CeO}_{2}$ and $\mathrm{ZnO}$ nanoparticles in soil cultivated soybean (Glycine max). ACS Nano 7 (2), 1415-1423.

Hu B, Shao S, Ni H, Fu Z, Hu L, Zhou Y (2020) Current status, spatial features, health risks, and potential driving factors of soil heavy metal pollution in China at province level. Environ. Pollut. 266, 114961. doi: 10.1016/j.envpol.2020.114961. Epub

Jahan S, Alias YB, Abubakar AF, Yussof I (2018) Toxicity evaluation of Zno and $\mathrm{TiO}_{2}$ nanomaterials in hydroponic red bean (Vigna angularis) plant: Physiology, biochemistry and kinetic transport. J. Environ. Sci. 1, http://dx.doi.org/10.1016/j.jes.2017.12.022.

Jin K, Cornelis WM, Schiette W, Lu JJ, Buysse T, Baert G, Wu H J, Yao Y, Cai DX, Jin JY, De Neve S, Hartmann R, Gabriels D (2008) Redistribution and loss of soil organic carbon by overland flow under various soil management practices on the Chinese Loess Plateau. Soil Use and Management, 24,181-191.

Kabata-Pendias A, Pendias H (2001) Trace Elements in Soils and Plants, third ed. ed. CRC Press, Boca Raton.

Kiekens L (1995) Zinc. In: Alloway, B.J. (Ed.), Heavy Metals in Soils, 2nd edn. Blackie Academic and Professional, London, pp. 284-305. 
Lajayer BA, Moghadam NK, Maghsoodi MR, Ghorbanpour M (2019) Phytoextraction of heavy metals from contaminated soil, water and atmosphere using ornamental plants: mechanisms and efficiency improvement strategies. Environmental Science and Pollution Research 26:8468-8484.

Leitenmaier B, Küpper H (2013) Compartmentation and complexation of metals in hyperaccumulator plants. Front Plant Sci. 4: 374.

Li H, Li Z, Xie S, Huang Y, Chen M, Xie T, Wang G (2022) Accumulation and distribution of zinc in rice plants (Oryza Sativa L.) growing in zinc contaminated paddy soils with biochar. Journal of Environmental Chemical Engineering 10(1):106811.

Lindsay WL, Norvell WA (1978) Development of a DTPA soil test for zinc iron manganese and copper. Soil Sci. Soc. Am. J. 42, 421-428.

Liu D, Li S, Islam E, Chen J, Wu J, Ye Z, Peng D, Yan W, Lu K (2015) Lead accumulation and tolerance of Moso bamboo (Phyllostachys pubescens) seedlings: applications of phytoremediation. J. Zhejiang Univ-Sci B. (Biomed \& Biotechnol.) 16:123-130.

Liu L, Li W, Song W, Guo M (2018) Remediation techniques for heavy metal contaminated soils: principles and applicability. Sci. Total Environ. 633, 206-219. https://doi.org/10.1016/j.scitotenv.2018.03.161.

Liu Y, Liu D, Zhao Q, Zhang W, Chen X, Xu S, Zou C (2020) Zinc fractions in soils and uptake in winter wheat as affected by repeated applications of zinc fertilizer. Soil \& Tillage Research 200:104612.

Marschner H (1995) Mineral Nutrition of Higher Plants, II. Academic Press, London. 
Mertens J, Smolders E (2013). Zinc, in: B.J. Alloway (Eds.), Heavy Metals in Soils: Trace Metals and Metalloids in Soils and Their Bioavailability, Springer, Dordrecht, Nederlands, pp. $465-493$.

Michael PI, Krishnaswamy M (2011) The effect of zinc stress combined with high irradiance stress on membrane damage and antioxidative response in bean seedlings. Environ. Exp. Bot. 74, $171-177$.

Miretzky P, Saralegui A, Cirelli AF (2004) Aquatic macrophytes potential for the simultaneous removal of heavy metals (Buenos Aires, Argentina). Chemosphere 57, 997-1005.

Mourato MP, Moreira IN, Leitão I, Pinto FR, Sales JR, Martins LL (2015) Effect of heavy metals in plants of the genus Brassica. Int. J. Mol. Sci. 16, 17975-17998.

Mukherjee A, Peralta-Videa JR, Bandyopadhyay S, Rico CM, Zhao L, Gardea-Torresdey JL, (2013) Physiological effects of nanoparticulate $\mathrm{ZnO}$ in green peas (Pisum sativum L.) cultivated in soil. Metallomics 6, 132-138.

Noulas C, Tziouvalekas M, Karyotis T (2018) Zinc in soils, water and food crops. J. Trace Elem. Med. Biol. 49, 252-260. https://doi.org/10.1016/ j.jtemb.2018.02.009.

Rai PK, Lee SS, Zhang M, Tsang YF, Kim KH (2019) Heavy metals in food crops: health risks, fate, mechanisms, and management. Environ. Int. 125, 365-385.

Ramakrishna B, Rao SSR (2013) 24-epibrassinolide maintains elevated redox state of AsA and GSH in radish (Raphanus sativus L.) seedlings under zinc stress. Acta Physiol. Plant 35, 1291e1302. Ramakrishna,

Sagardoy R, Morales F, López-illán AF, Abadía A, Abadía J (2009) Effects of zinc toxicity on sugar beet (Beta vulgaris L.) plants grown in hydroponics. Plant Biol. 11,339-350. 
578 Sarwar N, Rehim A, Kamran MA, Shaheen MR, Matloob A, Imran M, Ishaque W, Hussain S,

579

580

581

582

583

584

585

586

587 588

589

590

591

592

593

594

595

596

597

598

Shaheen MR, Ishaque W, Kamran MA, Matloob A, Rehim A, Hussain S (2017)

Phytoremediation strategies for soils contaminated with heavy metals: modifications and future perspectives. Chemosphere 171, 710e721.

Shehata HS, Galal TM (2020) Trace metal concentration in planted cucumber (Cucumis sativus L.) from contaminated soils and its associated health risks. J Consum Prot Food Saf $15: 205-217$.

Shi G, Cai Q (2009) Cadmium tolerance and accumulation in eight potential energy crops. Biotechnol Adv 27(5):555-561.

Sidhu GPS (2016) Physiological, biochemical and molecular mechanisms of zinc uptake, toxicity and tolerance in plants. J. Global Biosciences 5, 4603-4633.

Sidhu PGS, Bali AS, Singh HP, Batish DR, Kohli RK (2020) Insights into the tolerance and phytoremediation potential of Coronopus Didymus L. (Sm) grown under zinc stress. Chemosphere 244:125350.

SPSS (2012) SPSS version 20.0. SPSS Inc., Chicago

Vassilev A, Perez-Sanz A, Cuypers A, Vangronsveld J (2007) Tolerance of two hydroponically grown Salix genotypes to excess zinc. J. Plant Nutr. 30, 1471-1482.

Wang S, Zhao Y, Guo J, Zhou L( 2016) Effects of Cd, Cu and Zn on Ricinus communis L. growth in single element or co-contaminated soils: pot experiments. Ecol. Eng. 90, 347-351.

Wei Z, Van Le Q, Peng W, Yang Y, Yang H, Gu H (2021) A review on phytoremediation of contaminants in air, water and soil. J. Hazard. Mater. 403, 123658. 
Wu MX, Luo Q, Liu SL, Zhao Y, Long Y, Pan YZ (2018) Screening ornamental plants to identify potential Cd hyperaccumulators for bioremediation. Ecotoxicol. Environ. Saf. 162, 35e41. https://doi.org/10.1016/j.ecoenv.2018.06.049.

Yadav SK, Juwarkar AA, Kumar GP, Thawale PR, Singh S, Chakrabarti T (2009) Bioaccumulation and phyto-translocation of arsenic, chromium and zinc by Jatropha curcas L.: impact of dairy sludge and biofertilizer. Bioresour. Tech- nol. 100, 4616e4622.

Yahaghi Z, Shirvani M, Nourbakhsh F, Pueyo JJ (2019) Uptake and effects of lead and zinc on alfalfa (Medicago Sativa L.) seed germination and seedling growth: role of plant growth promoting bacteria. South African Journal of Botany 124:573-82.

YangYL, Ma T, Ding F,Ma HZ, Duan XH, Gao TP, Yao J (2017) Interactive zinc, iron, and copper-induced phytotoxicity in wheat roots. Environ. Sci. Pollut. Res. 24, 395-404.

Zhao F, Xi S, Yang X, Yang W, Li J, Gu B, He Z (2012) Purifying eutrophic riverwaters with integrated floating island systems. Ecol. Eng. 40, 53-60.

Zhou X, Wang S, Liu Y, Huang G, Hu H (2020) Coupling phytoremediation efficiency and detoxification to assess the role of $\mathrm{P}$ in the $\mathrm{Cu}$ tolerant Ricinus communis L. Chemosphere 247:125965.

Zou J, Song F, Lu Y, Zhuge Y, Niu Y, Lou Y, Pan H, Zhang P, Pang L (2021) Phytoremediation potential of wheat intercropped with different densities of Sedum Plumbizincicola in Soil contaminated with cadmium and zinc. Chemosphere 276:130223.

Rauch JN, Pacyna JM (2009) Earth's global Ag, Al, Cr, Cu, Fe, Ni, Pb, and Zn cycles,global biogeochem.Cycles,23, GB2001, doi:10.1029/2008GB003376. 
623 Napoli M, Cecchi S, Grassi C, Baldi A, Zanchi CA, Orlandini S (2019) Phytoextraction

624 of copper from a contaminated soil using arable and vegetable crops. Chemosphere 219, 122-129.

$625 \quad$ https://doi.org/10.1016/ j.chemosphere.2018.12.017 


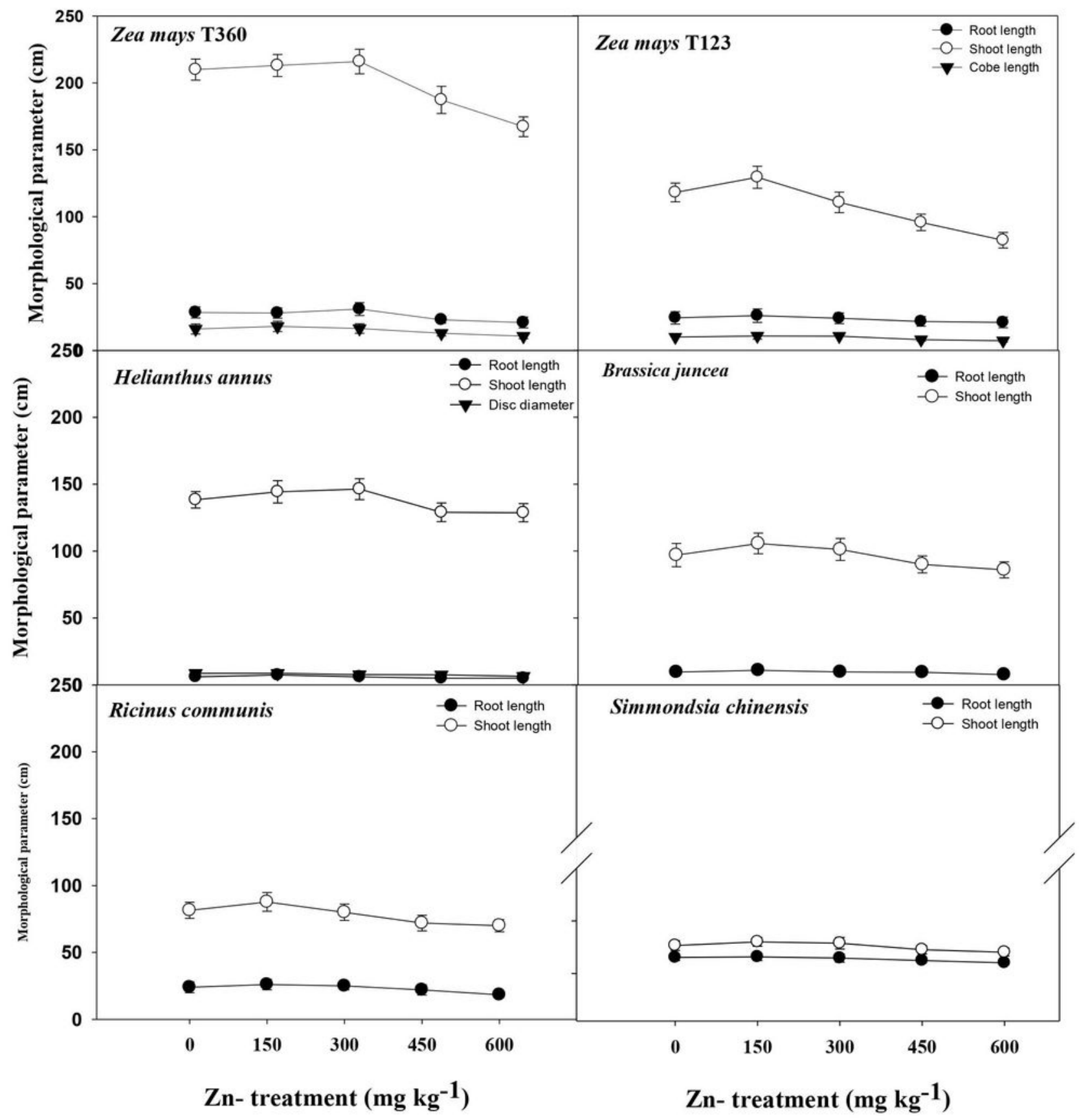

Fig. 1. Morphological measurements of the six oil crop plants grown under different $\mathrm{Zn}$ treatments for 100 days.

Figure 1

Please See image above for figure legend. 


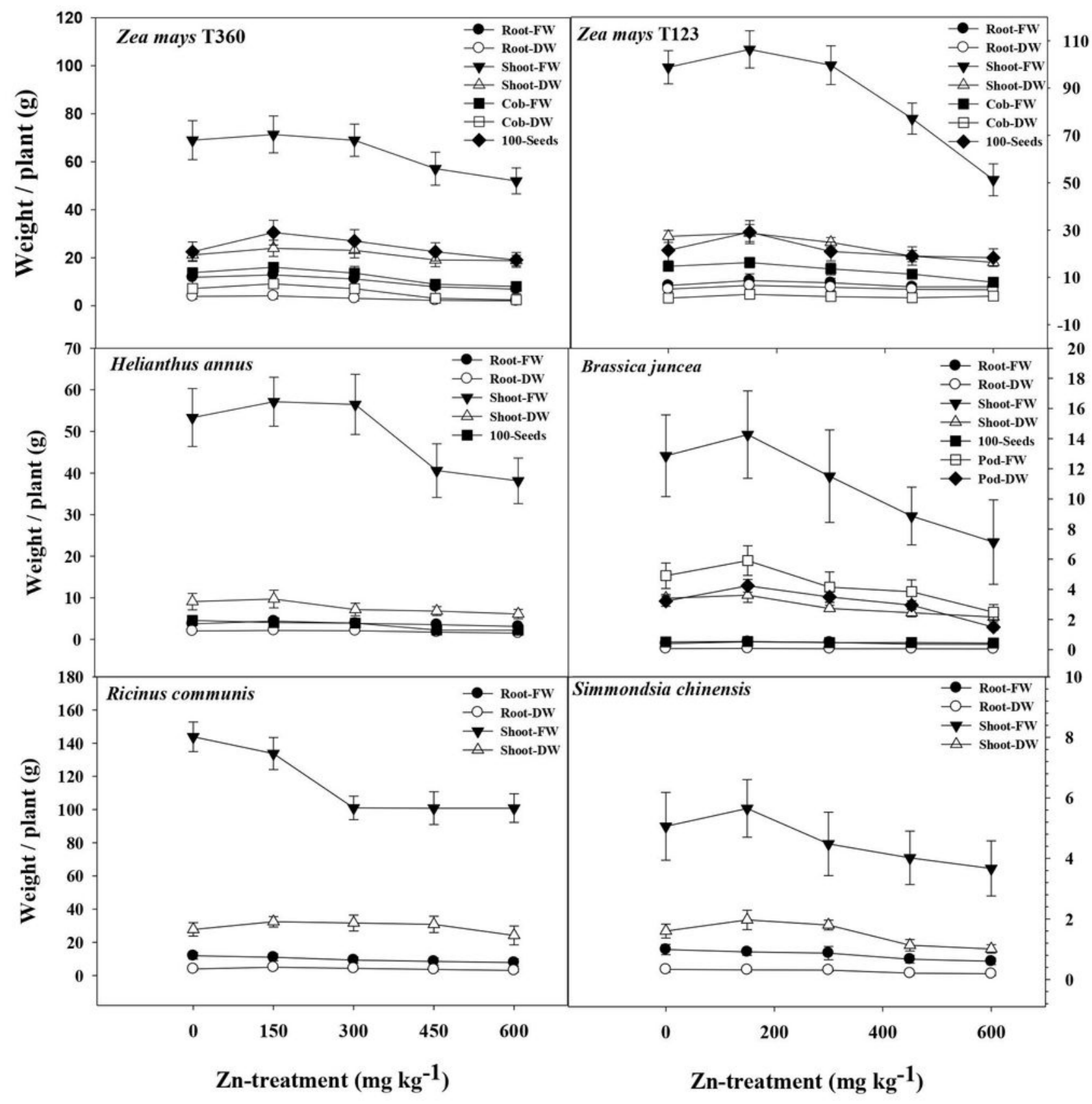

Fig. 2. Dry weight standing crop (g/plant) of the different organs of the six oil crop plants grown under different $\mathrm{Zn}$ treatments for 100 days. FW: fresh weight, DW: dry weight.

Figure 2

Please See image above for figure legend. 


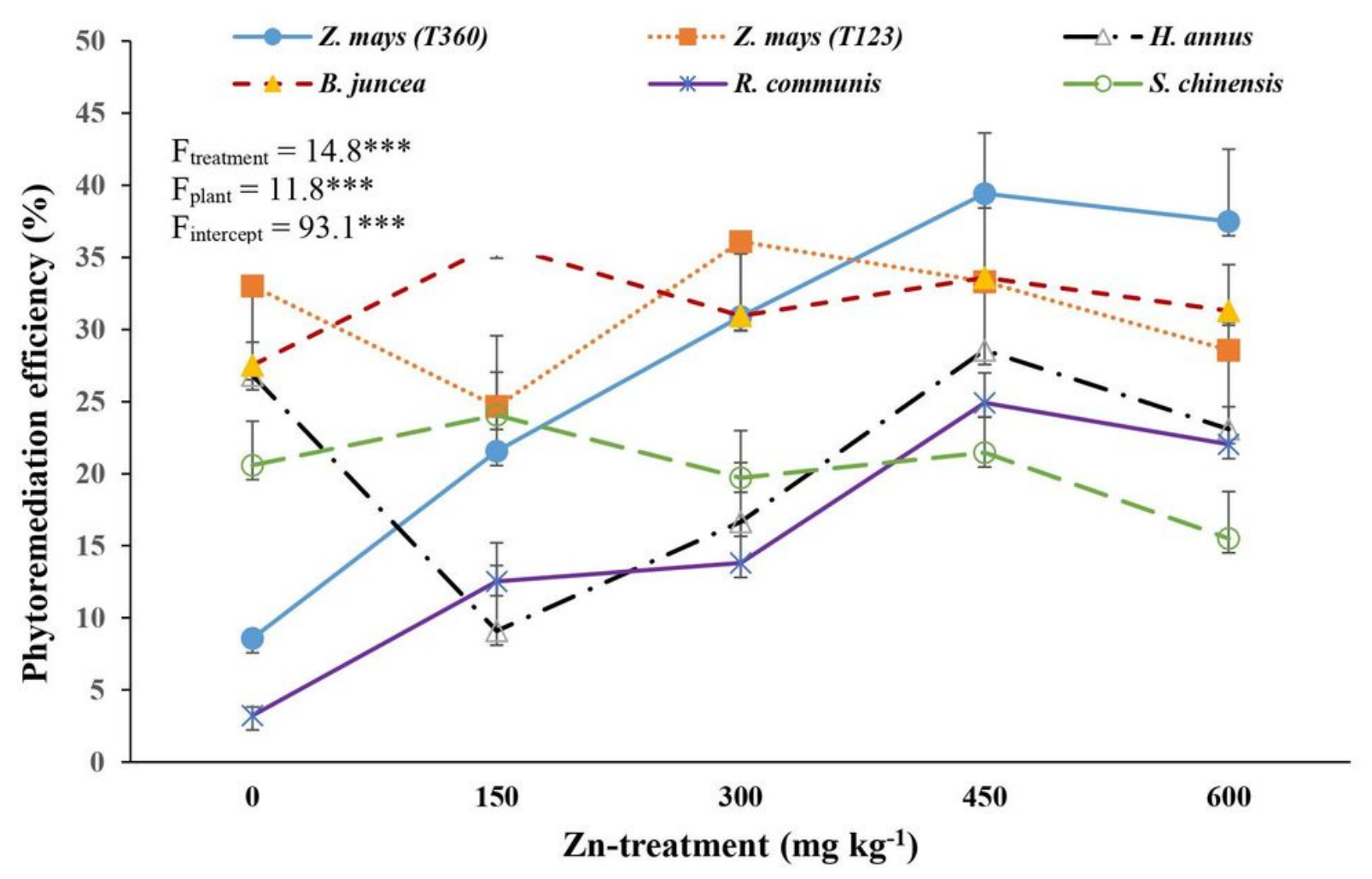

Fig. 3. Phytoremediation efficiency (\%) of the six oil crop plants grown under different $\mathrm{Zn}$ treatments for 100 days. Z. mays: Zea mays; H. annus: Helianthus annus; B. juncea: Brassica juncea; R. communis: Ricinus communis; S. chinensis: Simmondsia chinensis. ***: $P<0.001$.

Figure 3

Please See image above for figure legend.

\section{Supplementary Files}

This is a list of supplementary files associated with this preprint. Click to download.

- T1.jpg

- T2.jpg

- T3.jpg

- T4.jpg

- T5.jpg 